\title{
ECONOMIC IMPACT ANALYSIS OF
}

\section{Autonomous Containerised Freight}

SUBMITTED TO

Chief Scientist

\& Engineer

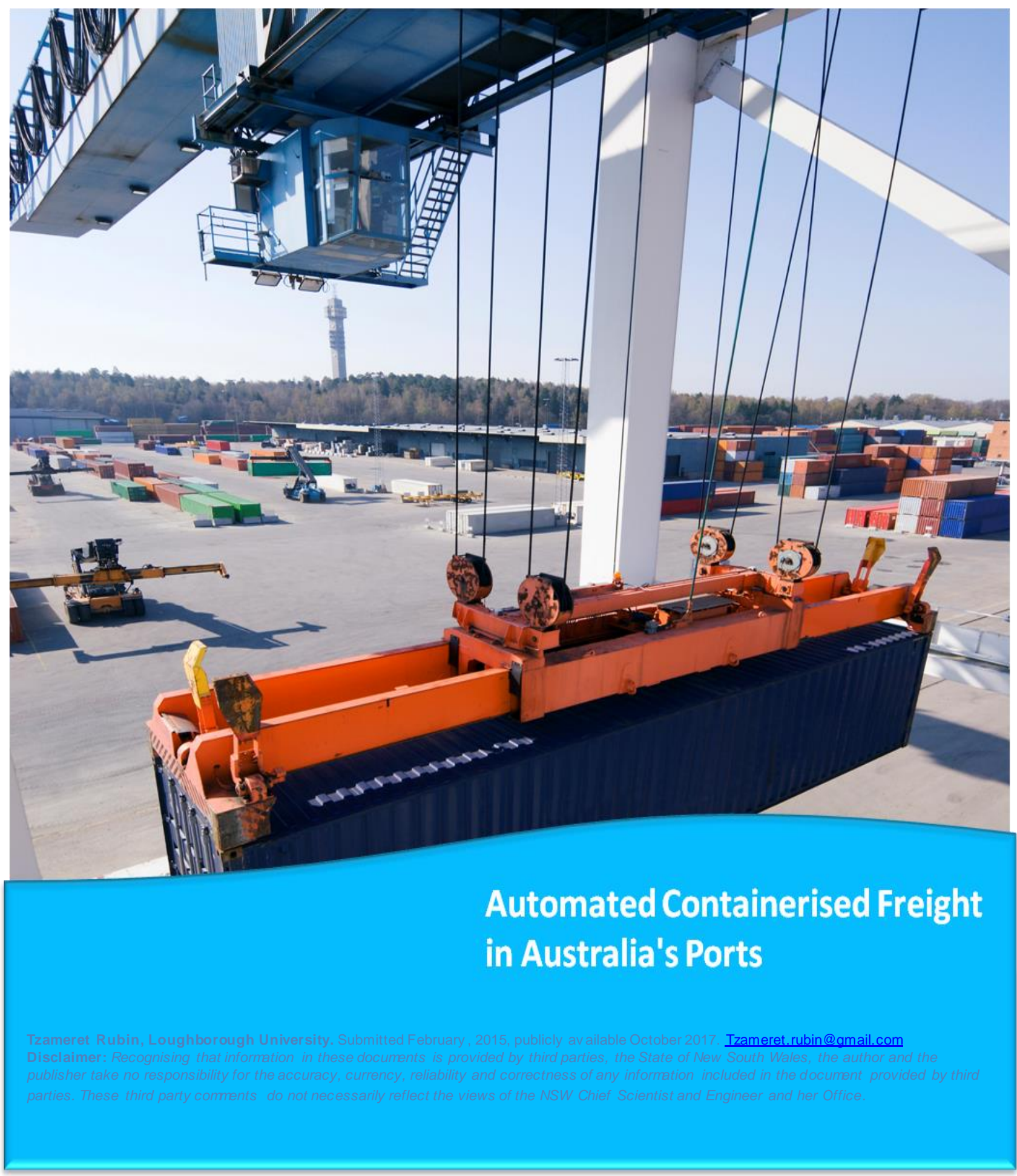




\section{EXECUTIVE SUMMARY}

Advanced robotics is a disruptive technology that has the potential to create massive economic impact. According to a McKinsey Global Institute study in 2013, advanced robotics were identified as one of twelve disruptive technologies to have an economic impact, with an estimated potential to affect $\$ 6.3$ trillion in labour costs globally (McKinsey, 2013).

One application of advanced robotics is the automation of cargo ports, with the intention of increasing profitability for cargo terminals by reducing costs and increasing container handling productivity. They comprise autonomous guided vehicle (AGV) robots equipped with radar and laser guidance technology to navigate and position containers in the optimum and most efficient manner, by minimising space allocation time and providing significant safety improvements.

The need to increase cargo capacity to support economic growth is a global trend, which is echoed by Australian reports that acknowledge the urgent need for freight capacity increase. Unless Australian ports are able to expand their capacity by improving their productivity, the growing technol ogy along the cargo supply chain will create a bottleneck in Australian ports that could hamper its economic growth. According to the Bureau of Infrastructure, Transport and Regional Economics (BITRE) data, in the year 2029-30, across Australia, ports will handle almost twice as much capacity as they do today. This capacity increase would require a significant improvement in using the nation's resources, through optimisation of space and transportation capabilities (BITRE, 2010).

The most significant contribution to Australian ports would result from a fully automated system that connects the terminal operating system (TOS) and equipment that would integrate and interface with the terminal logistic system (TLS). This report focuses on advanced robotics able to handle the cargo in Australia's ports, and provides an economic benefit analysis and forecast of moving towards automated autonomous straddle carriers across Australia. Currently Brisbane port operates a fully autonomous straddle carrier terminal, with another due to become operational in Botany Bay, Sydney in 2014. In January 2015 Kalmar announced that it has been awarded a contract to provide an integrated automation system to handle operations at Victoria International Container Terminal Ltd's (VICT) new terminal in Melbourne, Australia (Kalmar, 2015).

Autonomous straddle carrier technology can not only significantly improve freight capacity but can also enhance the safety of operations, reducing the potential for manual errors by isolating the workforce from heavy machinery. Patrick - one of Australia leading company for containers stevedoring services reports that in the first year of straddle automation at Brisbane terminal they achieved a $75 \%$ reduction in safety incidents that increased with a reduction of $90 \%$ in following years (Patrick, 2012) ${ }^{1}$.

Findings suggest a net present value (NPV) of autonomous straddle carrier technology in direct impact worth for NSW of around $\$ 9.42$ to $\$ 10$ billion between the years 2014 and

\footnotetext{
${ }^{1}$ Patrick is Asciano's terminal and logistics division. It is one of the two major competitors in the Australian market providing container stevedoring services in the four largest container ports in Australia: East Swanson Dockin Melbourne, Port Botany in Sydney, Fisherman Island in Brisbane and Fremantle in WA. (Asciano, 2013)
} 
2030. Nationally, the estimated NPV revenue gain ranges between around $\$ 32.1$ billion and $\$ 34.1$ billion. This study solely focuses on a specific automation technology - straddle carrier technology. A fully automated cargo port has the potential for increased economic impact. Therefore, a broader analysis of a fully automated system and its potential productivity increase should be considered.

A cost benefit analysis was not undertaken in this report as innovation studies show that any innovation outcome cannot capture the full benefit to the economy, therefore the costs are normally high and in most cases create no tangible benefit but creates intangibles like knowledge is not easy to be quantified. In this report we present only the final application of a long term process of university R\&D effort. Similarly, the safety benefits due to the introduction of this technology were addressed but they were not quantified. 


\section{CONTENTS}

Executive Summary 2

Contents 4

Abbreviations 5

Growing containerised volume in Australian ports $\quad 6$

Autonomous straddle carrier - autonomous guided vehicles implementation $\quad 7$

$\begin{array}{ll}\text { What is a fully auto mated cargo port? } & 7\end{array}$

Methodology 9

Inputs and Outputs of Innovation $\quad 9$

Growing Demand for Containerised Freight 9

$\begin{array}{ll}\text { Technology Adoption Rate } & 10\end{array}$

$\begin{array}{ll}\text { Indirect Effect } & 13\end{array}$

$\begin{array}{ll}\text { Addressing Manpower Displacement } & 13\end{array}$

$\begin{array}{ll}\text { Findings } & 15\end{array}$

Direct Economic Impact for NSW 15

Direct Economic Impact on a National Level 17

$\begin{array}{ll}\text { Summary } & 19\end{array}$

References $\quad 21$

$\begin{array}{ll}\text { Appendix } & 22\end{array}$ 


\section{ABBREVIATIONS}

ABS

ACCC

AGV

BITRE

DAE

GPS

MTBF

NPV

RBA

TEU

TLS

TOS
Australia Bureau of Statistics

Australian Competition and Consumer Commission (ACCC)

Autonomous Guided Vehicles

Bureau of Infrastructure, Transport and Regional Economics

Deloitte Access Economics

Global Positioning System

Mean Time Between Failures

Net Present Value

Reserve Bank of Australia

Twenty foot Equivalent Units

Terminal Logistic System

Terminal Operating System 


\section{GROWING CONTAINERISED VOLUME IN AUSTRALIAN PORTS}

Globally, containerised freight volume is expected to grow, largely due to the economic growth of the Asian markets. In Australia, according to a statistical report by BITRE (Bureau of Infrastructure, Transport and Regional Economics) Department of Infrastructure, Transport, Regional Development and Local Government ${ }^{2}, 2010$, national exports are expected to more than double in twenty-foot equivalent units (TEUs) ${ }^{3}$. The exported, imported and TEUs transported between Australian ports are as specified below:

- Australian containerised exports in 2007-08 totalled 1.50 million TEU. This is forecast to increase to 6.32 million TEU by 2029-30.

- Australian containerised imports in 2007-08 totalled 2.46 million TEU. This was forecast to increase to 2.67 million TEU in 2012-13, and to 5.17 million TEU by 2029-30.

- In 2007-08, there were 362000 TEU transported between Australian ports. This was forecast to increase to 415000 TEU in 2012-13, and to 824000 TEU by 2029-30.

Although forecasting through economic modelling techniques can be a challenge, The 2010 BITRE report's figures are still thought to be reasonably accurate. When cross referenced with 2011-12 Ports Australia data, the 2007 estimate was found to be $6.31 \%$ lower than the actual cargo freight data in 2011-12 - the most up to date actual data available today (BITRE,2010). It is therefore a reasonable assumption that the 2029-30 forecasts could also be higher than amounts presented above. Growing demand for commodities should also be considered. Globally, and in particular in Australia, ports are already facing demands for growth in capacity of transportation volume, which requires handling a bigger volume of cargo, either by physically expanding ports, or by increasing productivity with existing resources. Freight capacity must rise, not only because of macroeconomic factors such as growing demand for commodities, booming population and global isation processes, but also because along the supply chain technology will allow vessel sizes to scale up. In the 2006 Maritime Policy Planning Model report, the UN projected that vessels would increase in size to 12,000 TEU and beyond within the next decade (Transport, Communications, Tourism and Infrastructure Development Division of ESCAP, 2006). Today's vessels are even bigger than the UN forecast; carrying more than $18,000 \mathrm{TEU}$. This scaling up will push port management to address the growing capacity challenges of terminal handling.

\footnotetext{
${ }^{2}$ Now the Department of Infrastructure and Regional Development.

${ }^{3}$ A twenty-foot equivalent unit is a measure that quantifies the number of containers by their physical size.
} 


\section{AUTONOMOUS STRADDLE CARRIER - AUTONOMOUS GUIDED VEHICLES IMPLEMENTATION}

Autonomous straddle carrier robots are one implementation of AGVs. In general, AGVs are machines that perform automated outdoor handling activity - normally in a harsh environment - while complying with a very high safety standard. An AGV system needs to satisfy the following functionality requirements: (1) proven volume and capacity i.e., being able to achieve a duty cycle equivalent to or better than a manned vehicle; (2) compliance with outdoor working environment i.e., being able to work in any environment - weather and terrain; (3) reliable - very low mean time between failures (MTBF), and any failure should be identifiable; (4) and lastly, safety operation - being able to detect and respond to unexpected obstacles and events. AGV design includes a mechanical chassis, control system and add-on hardware architecture and navigation system (GPS and radar) that complies with all four requirements (H. Durrant-Whyte H. et.al, 2007).

A fully automated cargo port is operated remotely in real time. AGVs use sensors to allocate containers in the most efficient way, and then use radar to position the containers accurately, which allows optimisation in space and time. AGVs autonomously handle containers from the time the ship arrives at the port until delivery to the dealer. AGVs track all vehicle movements from the point of entry to wharf transport and all stages of processing, dispatch and delivery. The AGV s use bar code scanners to track containers and transmit their position and movements over radio. This provides real-time updates of the containers and vehicle's status.

\section{What is a fully automated cargo port?}

Cargo port automation is designed to achieve higher profitability for cargo terminals by reducing costs and increasing container-handling productivity. It is composed of AGV robots equipped with radar and laser guidance technology to navigate and position containers in the most efficient and optimised way, through minimising space allocation time and providing significant improvements in safety since the human error factor is removed (Patrick, 2012). A fully automated terminal offers a real time monitoring and tracking system which provides constant, predictable and reliable performance. It also ensures that the accurate location of each container is known, shortening handling times and avoiding searches. Automated cargo terminals are a preferred alternative to manual handling because the terminal assures a $24 / 7$ service without maximum allowable human workday limitations and other workforce limitations.

A fully automated terminal includes the following components (Kalmar, 2014):

- Autonomous straddle carriers are used for all functions: connecting transport, stacking on container storage and road truck handling.

- Autonomous shuttles create a buffer where the containers are placed by one piece of equipment to be picked up by other equipment when it becomes available. The buffer has several randomly accessible transfer positions, ensuring there is always a position to locate the next container. Through this arrangement, each set of apparatus can operate at its own optimum pace and best performance. 
- Autonomous stacking cranes are used to optimise container storage. By stacking cranes on rails, space is utilised in a very efficient way which means fewer vehicles are required to transport the same number of containers, reducing both the associated investment in equipment and overall maintenance costs.

- - A back office management software that is a supervision visualisation tool. It provides insight to the operators real-time data on the outdoor equipment positions.

The methodology for evaluating the potential economic benefit of using autonomous straddle carriers in Australia's cargo ports is described in the following section. 


\section{METHODOLOGY}

Before detailing the methodology for evaluating the direct economic benefit of automated straddle carriers, it should be noted that automation can not only increase the port's capabilities along the entire supply chain, but it also has a very significant contribution to port workers' safety by relocating workers to control rooms, rather than having them on-site between large pieces of machinery. This economic analysis does not quantify safety related issues, however, retained safety costs and any resulting workplace social changes could also be subjects for further study.

\section{Inputs and Outputs of Innovation}

Innovation studies have shown that any innovation outcome cannot capt ure the full benefit to the economy. This report does not present a cost-benefit analysis; it simply presents the application of a long term university R\&D effort - part of which we can measure by relying on some assumptions. However, a dollar value evaluation is provided to quantify the benefits in deploying automated straddle handling in cargo ports per state, providing government with the tools for further discussion regarding innovation in the transportation sector in Australia.

\section{Growing Demand for Containerised Freight}

The baseline for our analysis of Australian cargo ports' capacity is the 2010 BITRE report. According to this report, long-term containerised freight growth rate in Australia is expected to be $4 \%$ per annum (BITRE, 2010). The container trade is concentrated around five mainland capital ports: Adelaide, Brisbane, Fremantle, Melbourne, and Sydney. Around $90 \%$ of total container imports and exports were handled at one of these ports in 2007-08, and between them they were the origin of over $70 \%$ of the containers shipped domestically in that year (BITRE, 2010).

Figure 1 shows BITRE forecasts for containerised freight growth until the 2029-30 fiscal year. When comparing actual data - from Ports Australia and the BITRE forecast - we found that in the 2011-2012 financial year, the BITRE forecast was around 6.6 million TEU; however actual data from Port Australia showed that Australian ports handled 7.06 million TEU in that year, which makes the BITRE forecast an underestimation of $6.51 \%$. In our model we used the BITRE 2010 forecast to 2029-30 but adjusted for the underestimation, by allowing additional $6.51 \%$ to their yearly forecast. 
Figure 1: Expected Growth of Containerised Freight (BITRE, 2010)

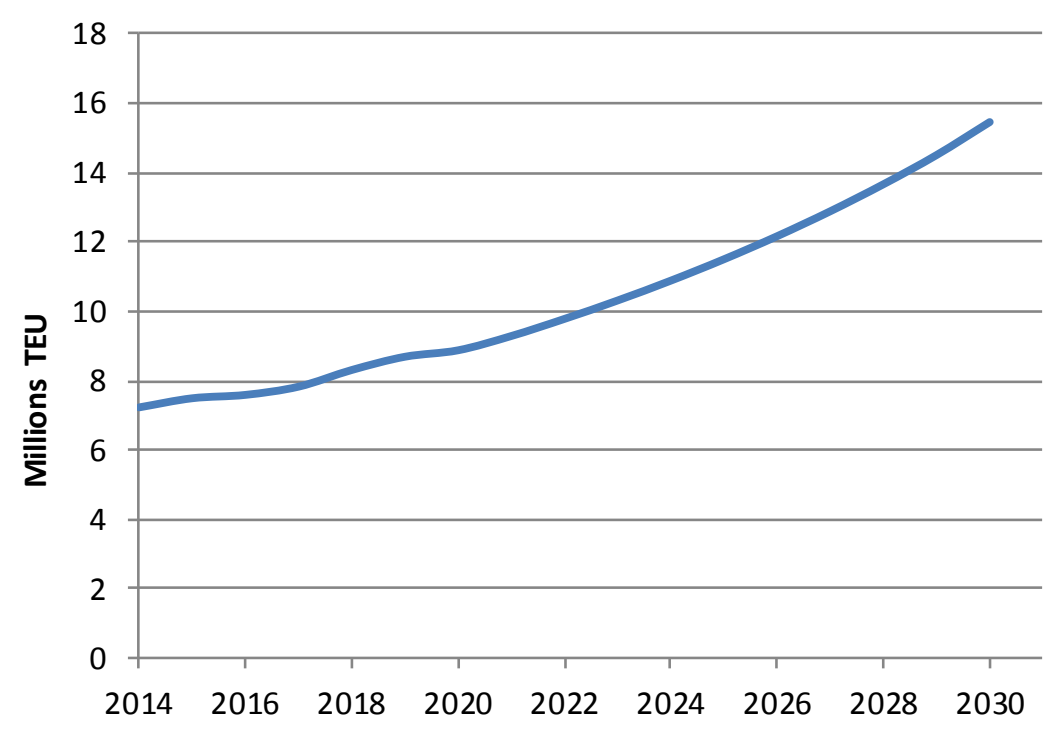

\section{Technology Adoption Rate}

To structure a thorough analysis, data with a gradual adoption rate was applied between the years 2014 and 2030 -- a period of 17 years. According to technology experts and union managers, this timeframe is reasonable to allow this industry to adopt such technology. Australian cargo ports are a centralised industry that can encourage a faster adoption rate ${ }^{4}$. According to Ports Australia data from 2011-12, 92.4\% of Australia's cargo trade was handled in only 13 ports in the states of NSW, VIC, WA and QLD. However, a lack of competition could impede the adoption of new technologies.

In recent years, there have been signs that globalisation is affecting the industry, with foreign companies identifying the potential to increase cargo trade in Australia, investing in Australia's ports to compete with the current working ports by automating cargo handling, thereby reducing costs. This competition would encourage a faster adoption rate of the technology.

Support for a more gradual adoption rate can be gained by referring to a 2012 Deloitte Access Economics (DAE) report. Figure 2 shows how the transportation industry was found to have a slow adoption rate; it ranked quite high for the duration required per firm to adopt a disruptive innovation, as can be seen in Figure 2, it will take around 4.5 years for the Australian economy to adopt a disruptive technology in that industry ${ }^{5}$. In our analysis however, our unit of impact measurement (axis y) is the potential revenue increase attributed to the adopted innovation, while DAE relates to impact as a percentage change in business.

\footnotetext{
${ }^{4}$ In Centralised we mean that changing over would be relatively easy since there are only 5 main ports and all of their parts are in the same area

${ }^{5}$ In contrast to the Transport industry, the Retail and Trade industry for example, is a fast moving industry that requires around half a year to adopt a technology that would have the potential to change the industry and reflect on other industries, i.e., a disruptive technology.
} 
Figure 2: Technological Innovation Diffusion

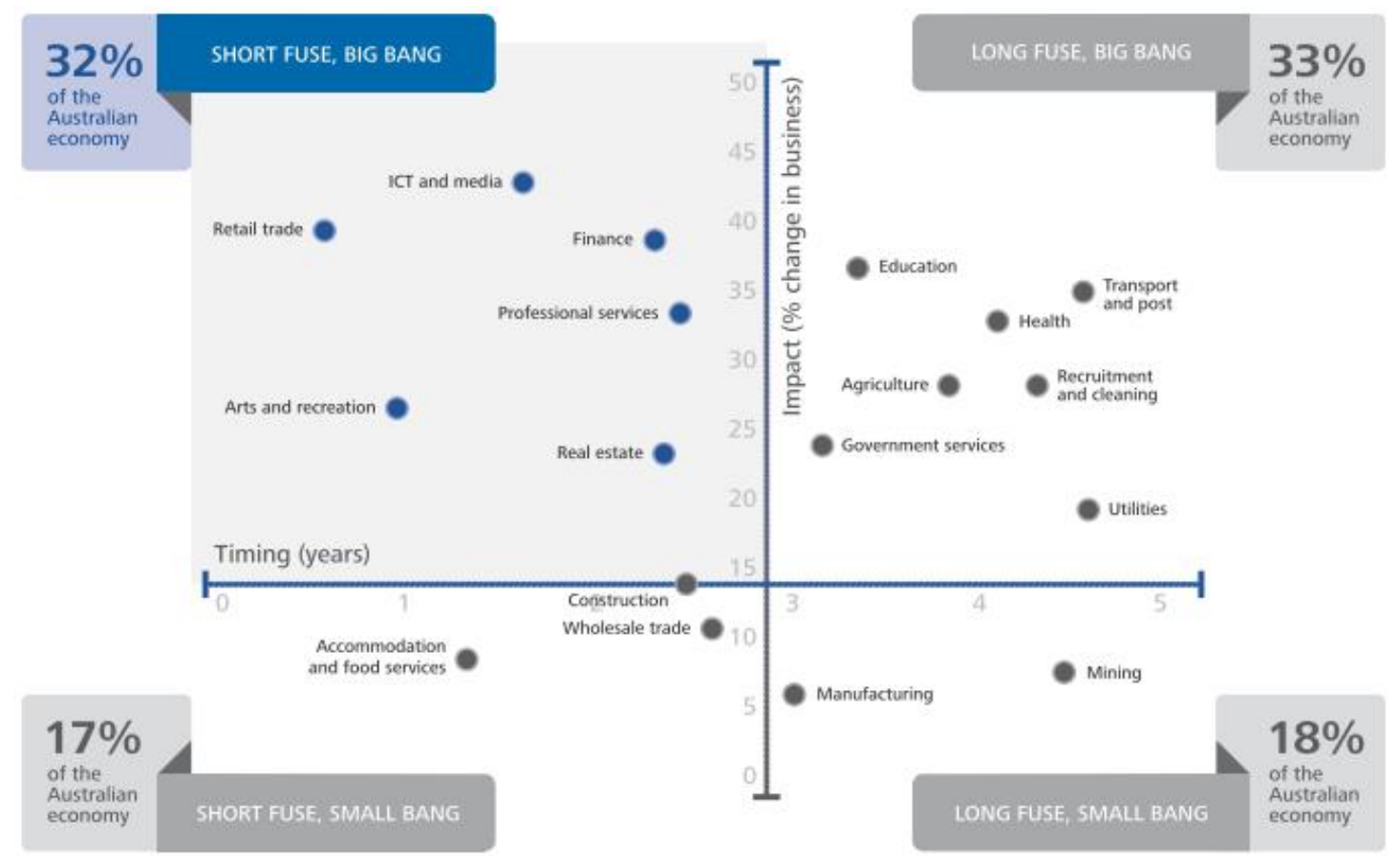

Source: Deloitte Access Economics: Digital disruption-Short fuse, big bang, 2012

The productivity growth achieved through a higher TEU capacity handling is critical in this model due to the argument that in addition to expected growth with the known technology of stevedoring productivity, applying automation in cargo straddle handling will increase productivity even further.

Allowing for every year between 2014 and 2030, a 1.65\% reduction of costs and a $2.29 \%$ increase in productivity were estimated, while to forecast capacity growth, the BITRE 2010 report was referenced. A detailed description of cost reduction and capacity growth calculations is provided in Appendix A. Here, the argument is that on top of the predicted capacity growth due to growing demand and globalisation trends, a gradual adoption of the technology would induce growing volume of TEU handling for all states, across Australia.

As pricing perTEU varies with ship size, an allowance for the low and high range of estimation is used (BITRE 2011). Freight pricing was analysed, with the breakdown of import and export costs perTEU composed of the following components:

- Ship-based charges

- Cargo-based charges

- Stevedoring

- Customs brokers'fees

- Road transport charges 
TEU handling costs were collected by BITRE from relevant port authorities/corporations of ship call data, price schedules of relevant port authorities/corporations, towage operators and pilotage service providers and from surveys of customs brokers and road transport operators; stevedoring charge data was supplied by the Australian Competition and Consumer Commission (ACCC) (ACCC, 2010).

An assumption leap, in relation to microeconomics rules is then employed. While the data provides TEU capacity increase and charges per TEU handling, to calculate the total revenue increase, it is necessary to combine the two inputs to find how the technology can result in revenue increase.

Each port will have its own costs, however the national and state level data relates to production capacity, not TEU charges per port. Therefore linking TEU charges to production capacity increase relies on TEU charges composed of TEU handling per unit (dollar) times the TEU quantity in each port.

Assuming port managers would gradually adopt the technology, they face two options: (1) reduce cost of production and maintain the fixed production quantity, or (2) allow fixed cost of production and increase the production capacity ${ }^{6}$. Both approaches produce the same outcome; however here the second approach is adopted, under the assumption that port management chooses to increase production capacity, due to growing global cargo trade and the marginal costs are still below the marginal benefit. Economically speaking, this means port management companies would maximise their profits by producing more. These assumptions were not supported by demand and supply data; however it is a reasonable assumption because of growing cargo trade capacity, and increasing demand for commodities and global competition in Australian ports for TEU handling ${ }^{7}$.

The two scenarios (low and high), allow for sensitivity analysis and provide the benchmark for further calculation of production volume increase and its associated value. As mentioned previously, future technological improvements in maritime trade, such as ship capacity increase, or automation of port components (e.g. a full terminal operating system that would integrate with the terminal logistic system) cannot be accounted for. However, it is assumed the innovation would have a positive effect on port cargo capacity, by the specified percentages. In other words, the 'technology' variable is held fixed over the years, with a potential for even higher growth in productivity by further technological innovations.

Next, this was referenced to the states' capabilities and the aggregated national level of productivity increase.

\footnotetext{
${ }^{6}$ In this cost analysis, we referenced the variable cost, and not the fixed costs. It is evident that such an investment in buying heavy equipment like autonomous straddle carrier technology is very expensive; however (1) a cost-benefit analysis was not undertaken in this case study (because innovation has tangibles and intangibles that cannot be quantified to provide evidence for benefit), and (2) to make a decision regarding variable cost and not fixed cost, a further dependant analysis regarding quantityincrease that affects the variable costs would be required.

7 Port Jackson Partners 2011 report that due to Australia's geographical proximity to Asian markets and its wealth of resources, there is a growing demand for resources that will have a positive effect on Australian economic growth for many years a head.
} 
Table 1 shows that by the year 2030, handling capacity in Australian ports across the country is predicted to more than double current volume. This predicted capacity increase would require a significant improvement in the nation's space and transportation resources.

Table 1: TEU Capacity Increase, by State, According to BITRE 2010 Forecast

\begin{tabular}{|cccccccccc|}
\hline State & 2014 & 2015 & 2016 & 2017 & $\cdots$ & 2027 & 2028 & 2029 & 2030 \\
VIC & $2,646,471$ & $2,742,538$ & $2,778,245$ & $2,865,039$ & & $4,715,455$ & $5,000,179$ & $5,308,626$ & $5,656,648$ \\
NSW & $2,120,511$ & $2,197,485$ & $2,226,096$ & $2,295,641$ & & $3,778,305$ & $4,006,443$ & $4,253,589$ & $4,532,445$ \\
QLD & $1,102,055$ & $1,142,060$ & $1,156,929$ & $1,193,072$ & & $1,963,631$ & $2,082,197$ & $2,210,642$ & $2,355,567$ \\
WA & 705,323 & 730,926 & 740,443 & 763,575 & & $1,256,738$ & $1,332,621$ & $1,414,826$ & $1,507,579$ \\
SA & 332,292 & 344,354 & 348,837 & 359,735 & & 592,074 & 627,824 & 666,552 & 710,250 \\
TAS & 322,784 & 334,501 & 338,857 & 349,443 & & 575,134 & 609,861 & 647,482 & 689,929 \\
TOTAL & $\mathbf{7 , 2 3 1 , 4 5 1}$ & $\mathbf{7 , 4 9 3 , 8 7 9}$ & $\mathbf{7 , 5 9 1 , 4 2 2}$ & $\mathbf{7 , 8 2 8 , 5 2 2}$ & - & $\mathbf{1 2 , 8 8 3 , 3 6 2}$ & $\mathbf{1 3 , 6 6 1 , 1 5 1}$ & $\mathbf{1 4 , 5 0 3 , 7 4 6}$ & $\mathbf{1 5 , 4 5 4 , 4 4 9}$ \\
\hline
\end{tabular}

Source: Based on Ports Australia 2011-12 cargo data, and BITRE 2010 'Australian Maritime Activity to 2029-30'.

\section{Indirect Effect}

The analysis in this paper deals with the direct economic impact of port automation. Indirect economic impacts, such as changes in industry structure have not been accounted for. The effect of increasing capacity of cargo trades should be addressed separately in a more comprehensive approach, encompassing all cargo transportation handling components, inside and outside the ports. Also not included in the analysis was the 'downstream effect' value added for complementary industries, and how the capacity increase of TEU handling can affect the entire supply chain of commodities in Australia. The fact that more cargo could be handled across Australia faster than before could increase international trade exporting and importing capabilities.

Finally, the production volume increase and its associated value over the years from 2014 to 2030 was calculated, and provided the NPV of 17 years with a gradual adoption of the technology. From this allows a potential average increase of volume and value peryear for the next 17 years can be determined.

\section{Addressing Manpower Displacement}

Technological change is the evolution of industrial society in all fields. However, workforce displacement, driven by the need to reduce production costs, is an issue that requires careful consideration. .

Technology is 'pushed' or 'pulled' to improve productivity and allow organisations to become more competitive; these market forces cannot be stopped unless government regulation is put in place and enforced. As part of the analysis, representatives from the Maritime Union of Australia were interviewed to gain insight into the relationship between the unions and port management in relation to automated cargo port technology, and the processes that allowed for the introduction of new technol ogies to some ports.

In this analysis Patrick's description of the automation process was also referred to, detailing how employees were trained to work in back offices rather than be laid off by the company due to robots doing their job on site. This shift in employees ' work locations has huge advantages in health and security issues. According to Patrick in the technology change 
process their employees were offered redeployments, agreed redundancy payments or training programmes. (Patrick, 2012)

According to a Maritime union official, a unionised workforce in historical disputes has been considered as one of the port's' stakeholders'. That is, if the port is going through a productivity change -- whether by introducing new technology that increases production capacity or by voluntary redundancies -- to gain collaboration with unions, the benefit from the productivity increase should be shared between all stakeholders: the workers and the owners.

Although resolution can be found with unions, two major problems may delay the introduction of a more efficient maritime transportation, in general and in particular cargo freight. These are:

1. Australia's large ports are too widely separated from each other to allow proper competition; therefore there is no real incentive to reduce prices.

2. There is a genuine problem of 'bottle necks' around the ports. Trucks are the primary method of cargo transportation across Australia, blocking major roads, and railways do not get close enough to ports to allow efficient freight handling. 


\section{FINDINGS}

The analysis allows for a generalisation of our findings to States and national levels, with a careful detailed proportion of production capacity of each state by its ports. In this section, based on the explanations provided in the methodology section, the potential production increase in volume and value are presented.

\section{Direct Economic Impact for NSW}

When combining all inputs to create the forecast of cargo capacity growth our findings suggest that in NSW, automated containerised freight has the potential to increase import revenue in the first year by between $\$ 33.4$ to $\$ 35$ million while export would yield $\$ 30.8$ to $\$ 33.1$ million in the same year. Starting in the year 2030, if all NSW ports were to adopt the technology, then a full $39 \%$ capacity growth would be achieved, with total cargo revenues predicted to be between $\$ 3.58$ billion to $\$ 3.8$ billion more than without straddle automation technology. The baseline comparison is a constant growth of TEU capacity handling for both import and export, as suggested by BITRE, while additional capacity growth is predicted due to the use of automation in TEU handling. Table 2 shows the potential revenue increase in NSW due to the productivity improvement.

The NPV of autonomous straddle carrier technology potential revenue increase in NSW can reach $\$ 9.42$ to around $\$ 10$ billion between the years 2014 and 2030 .

Table 2 NSW Revenue Increase (Million Dollars)

\begin{tabular}{|c|cc|cc|cc|}
\hline year & \multicolumn{2}{|c|}{ Import } & \multicolumn{2}{c|}{ Export } & \multicolumn{2}{c|}{ Total } \\
\hline & low & high & low & high & low & high \\
$\mathbf{2 0 1 4}$ & 33.4 & 35.0 & 30.8 & 33.1 & 64.1 & 68.1 \\
$\mathbf{2 0 1 5}$ & 71.1 & 74.6 & 65.5 & 70.5 & 136.5 & 145.0 \\
$\mathbf{2 0 1 6}$ & 110.9 & 116.4 & 102.2 & 110.0 & 213.1 & 226.4 \\
$\mathbf{2 0 1 7}$ & 156.7 & 164.4 & 144.4 & 155.3 & 301.1 & 319.8 \\
$\mathbf{2 0 1 8}$ & 213.5 & 224.1 & 196.8 & 211.7 & 410.3 & 435.8 \\
$\mathbf{2 0 1 9}$ & 275.3 & 289.0 & 253.8 & 273.0 & 529.1 & 561.9 \\
$\mathbf{2 0 2 0}$ & 337.0 & 353.8 & 310.7 & 334.2 & 647.7 & 688.0 \\
$\mathbf{2 0 2 1}$ & 414.0 & 434.6 & 381.6 & 410.5 & 795.7 & 845.1 \\
$\mathbf{2 0 2 2}$ & 503.9 & 528.9 & 464.5 & 499.7 & 968.4 & $1,028.6$ \\
$\mathbf{2 0 2 3}$ & 606.4 & 636.5 & 559.0 & 601.3 & $1,165.4$ & $1,237.8$ \\
\hline $\mathbf{2 0 2 4}$ & 723.3 & 759.2 & 666.7 & 717.1 & $1,389.9$ & $1,476.3$ \\
$\mathbf{2 0 2 5}$ & 856.5 & 899.0 & 789.4 & 849.2 & $1,645.9$ & $1,748.2$ \\
\hline $\mathbf{2 0 2 6}$ & $1,008.3$ & $1,058.4$ & 929.4 & 999.8 & $1,937.7$ & $2,058.1$ \\
$\mathbf{2 0 2 7}$ & $1,181.4$ & $1,240.1$ & $1,089.0$ & $1,171.4$ & $2,270.4$ & $2,411.5$ \\
\hline $\mathbf{2 0 2 8}$ & $1,378.9$ & $1,447.4$ & $1,271.0$ & $1,367.2$ & $2,649.9$ & $2,814.6$ \\
$\mathbf{2 0 2 9}$ & $1,604.2$ & $1,683.8$ & $1,478.6$ & $1,590.6$ & $3,082.8$ & $3,274.4$ \\
\hline $\mathbf{2 0 3 0}$ & $1,865.8$ & $1,958.4$ & $1,719.7$ & $1,850.0$ & $3,585.5$ & $3,808.4$ \\
\hline Source: Pros & & & & & \\
\hline
\end{tabular}

Source: Processed by TZAMERET RUBIN INNOVATION CONSULTANGES 
Figure 3 shows the predicted growth of TEU capacity in NSW (with and without the technology). It shows that in NSW alone, the new technology can have a significant gradual effect on the number of containers that the state's ports can handle. Without the automation of TEU handling, the capacity is expected to reach 4.8 million containers per year; however with automated cargo ports, the capacity can reach around 6.7 million containers peryear.

Figure 3 NSW TEU Capacity Growth due to the Introduction of Autonomous Straddle Carrier Technology

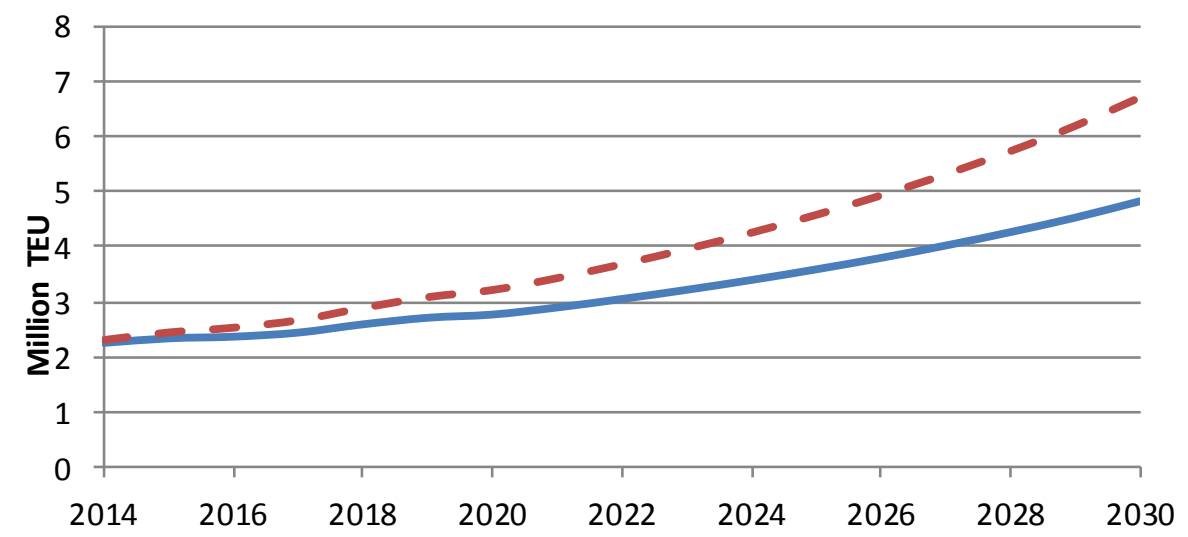

Source: Processed by TZAMERET RUBIN INNOVATION CONSULTANGES

- With cargo a utomation, Without autonomous straddle carrier technology

Table 3 shows NSW to be one of the States that can benefit the most from the introduction of autonomous straddle carrier technology, with the predicted productivity increase only slightly lower than Victoria. The two states combined account for more than $65 \%$ of all Australia's increase in cargo handling. This growth may have a significant impact on all indirect economic growth factors, as cargo freight affects many industries indirectly and has a direct link to the general transportation industry. All indirect economic effects are not taken into account in this analysis; however it is reasonable to assume that the effect of such an improvement in technology, in such an important area for many industries, may have an even bigger indirect effect on the entire economy.

Table 3 NPV of Revenue Increase by State, 2014-2030 (Billion Dollars)

\begin{tabular}{|lcc|}
\hline NPV & Low NPV 17 years & High NPV 17 years \\
\hline VIC & 11,768 & 12,499 \\
NSW & 9,429 & 10,015 \\
QLD & 4,900 & 5,205 \\
WA & 3,136 & 3,331 \\
SA & 1,478 & 1,569 \\
TAS & 1,435 & 1,525 \\
Total & $\mathbf{3 2 , 1 4 6}$ & $\mathbf{3 4 , 1 4 5}$ \\
\hline
\end{tabular}

Source: Processed by TZAMERET RUBIN INNOVATION CONSULTANaES 


\section{Direct Economic Impact on a National Level}

The use of autonomous straddle carriers in Australia's ports can provide an increase in capacity, allowing for future challenges in growing demand for cargo handling. Increasing cargo volume will be caused by many macroeconomic factors including population growth, technology progress - allowing increased cargo volume on ships, globalisation trends.

Capacity increase can yield revenues that could reach up to around $\$ 11.3$ to $\$ 12.9$ billion in 2030 , and accumulated NPV revenue of \$32.1 - \$34.1 billion over 17 years of deployment on a national level.

Table 4 National Level Revenue Increase (Million Dollars)

\begin{tabular}{|c|c|c|c|c|c|c|}
\hline year & \multicolumn{2}{|c|}{ Import } & \multicolumn{2}{|c|}{ Export } & \multicolumn{2}{|c|}{ Total } \\
\hline $\begin{array}{l}\text { Sensitivity } \\
\text { Analysis }\end{array}$ & low & high & low & high & low & high \\
\hline 2014 & 114 & 119 & 105 & 113 & 219 & 232 \\
\hline 2015 & 242 & 254 & 223 & 240 & 337 & 494 \\
\hline 2016 & 378 & 397 & 349 & 375 & 591 & 772 \\
\hline 2017 & 534 & 561 & 492 & 530 & 870 & 1,090 \\
\hline 2018 & 728 & 764 & 671 & 722 & 1,205 & 1,486 \\
\hline 2019 & 939 & 985 & 865 & 931 & 1,593 & 1,916 \\
\hline 2020 & 1,149 & 1,206 & 1,059 & 1,139 & 1,998 & 2,345 \\
\hline 2021 & 1,412 & 1,482 & 1,301 & 1,400 & 2,450 & 2,881 \\
\hline 2022 & 1,718 & 1,803 & 1,584 & 1,703 & 2,995 & 3,507 \\
\hline 2023 & 2,067 & 2,170 & 1,906 & 2,050 & 3,624 & 4,220 \\
\hline 2024 & 2,466 & 2,588 & 2,273 & 2,445 & 4,340 & 5,033 \\
\hline 2025 & 2,920 & 3,065 & 2,691 & 2,895 & 5,157 & 5,960 \\
\hline 2026 & 3,438 & 3,608 & 3,169 & 3,409 & 6,088 & 7,017 \\
\hline 2027 & 4,028 & 4,228 & 3,713 & 3,994 & 7,150 & 8,222 \\
\hline 2028 & 4,701 & 4,934 & 4,333 & 4,661 & 8,361 & 9,596 \\
\hline 2029 & 5,469 & 5,741 & 5,041 & 5,423 & 9,742 & 11,164 \\
\hline 2030 & 6,361 & 6,677 & 5,863 & 6,307 & 11,332 & 12,984 \\
\hline
\end{tabular}

Source: Processed by TZAMERET RUBIN INNOVATION CONSULTANGES

Table 5 and Figure 4 show that according to our analysis the expected TEU capacity will gradually climb to around 23 million TEU on a national level by the year 2029-30, which is expected to satisfy TEU demand for handling containers across Australia according to BITRE forecasts for the year 2029-308.

The average revenue increase by a gradual implementation of autonomous straddle carrier technology across Australia's ports over 17 years estimation ranges between $\mathbf{\$ 1 . 9 - \$ 2 ~ b i l l i o n ~ e v e r y ~ y e a r . ~}$

${ }^{8}$ To simplify the table presentations we write year "2030" however it relates to the fiscal year 2029 30 , the same applies to all other fiscal years. 
Table 5 Estimated TEU Capacity (Million TEU)

\begin{tabular}{|c|c|c|c|c|c|c|c|c|c|c|}
\hline & 2014 & 2015 & 2016 & 2017 & 2018 & $\ldots$ & 2027 & 2028 & 2029 & 2030 \\
\hline Million TEU & 7.86 & 8.33 & 8.62 & 9.08 & 9.84 & $\cdots$ & 18.09 & 19.52 & 21.08 & 22.83 \\
\hline
\end{tabular}

Source: Processed by TZAMERET RUBIN INNOVATION CONSULTANGES

Figure 4 Gradual growth rate of containerised freight capacity, national level

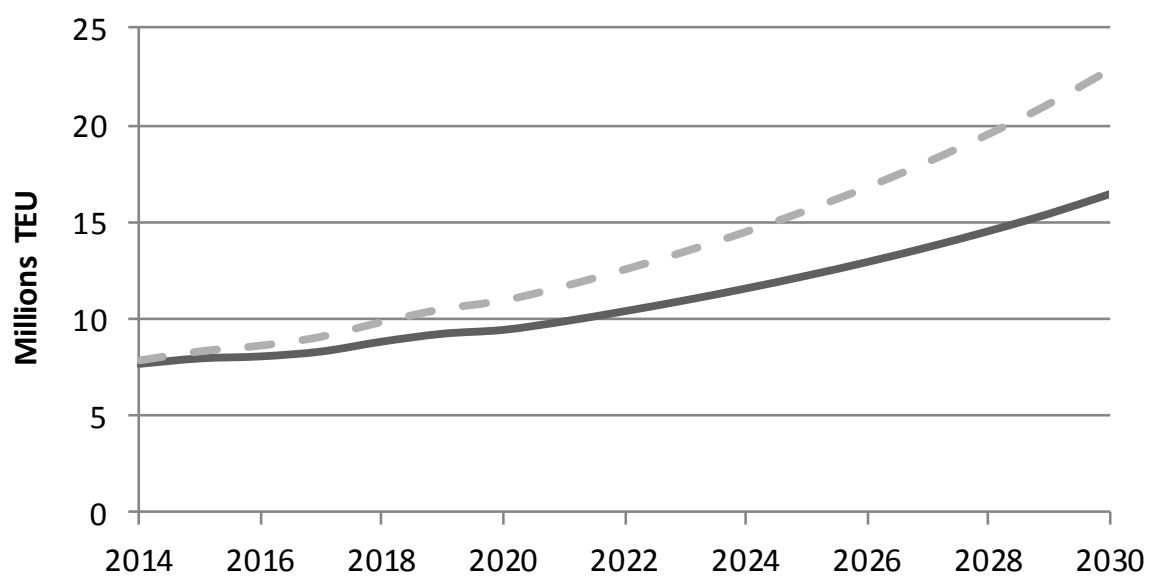

Source: BITRE, 2010 adjusted by a ctual data from Ports Aus tralia 2011-12

$=$ With automation technology due to $39 \%$ increa se in ca pacity,

no technology.

This data shows that on a national level, automating Australia's cargo ports can have a significant gradual expansion effect on the number of containers handled. Although in the first few years the differences between an automated and non-automated cargo port is low (around 176,000 containers). By the year 2030, TEU handling is expected to expand port capacity to 16.4 million containers without automation while with automation, the capacity is expected to reach around 22.8 million containers per year, which is around three times the capacity today.

The total revenue increase for both import and export is estimated to reach between $\$ 32.1$ billion and \$34.1 billion, as shown in Table 6. The calculation was the NPV at a national level for all years revenue increase due to autonomous straddle carrier technology.

Table 6 NPV of Revenue Increase (Billion Dollars)

\begin{tabular}{|c|c|c|}
\hline & $\begin{array}{c}\text { NPV } \\
\text { High Estimation }\end{array}$ & $\begin{array}{c}\text { NPV } \\
\text { Low Estimation }\end{array}$ \\
\hline Import & $\$ 17,558$ & $\$ 16,728$ \\
\hline Export & $\$ 16,586$ & $\$ 15,419$ \\
\hline Total & $\$ 34,145$ & $\$ 32,146$ \\
\hline
\end{tabular}

Source: Processed by TZAMERET RUBIN INNOVATION CONSULTANAES 


\section{SUMMARY}

This case study looks at a specific implementation of autonomous guided vehicles, including the autonomous straddle carrier, to examine the potential to improve Australia's ports cargo productivity if the technology is gradually deployed over the coming 17 years, until the year 2029-30. Autonomous straddle carrier technology automatically moves shipping containers in a port environment. The technology is fully automated using sensors and radar systems, providing a very accurate allocation of containers and a safe environment for port staff Durrant-Whyte (2007).

The analysis allows for a gradual adoption rate for all Australia's ports to implement the technology. Forces that would stimulate faster deployment of the technology include globalisation factors that increase competition in Austral ia's ports, the need to handle more cargo every year, and the fact that the ports industry is a very concentrated industry. Automating ports requires a significant investment in machinery and ICT systems - a process that may take years to become operational. However, this analysis is not a cost benefit analysis and it was not made to promote a technology and find the return on investment, but to provide estimation for the economic benefits while the private and publicsectors should identify the potential and need to promote this technology in the Aust ralian economy in the next coming years. Adoption of this technology also requires port management to handle their worker's unions, finding creative solutions to manage staff by either training them so that they can transfer their skills to work in control rooms, or by an agreed voluntary redundancy process. For these reasons, the analysis allows for a very gradual adoption rate, with the technology reaching its maximum in the year 2029-30.

The demand for a larger cargo capacity in the coming years is apparent al ready, vessels are getting bigger and more commodities are being shipped across the oceans. BITRE forecasts that in the year 2029-30, Australian ports would require almost twice as much handling capacity as they do today, while according to our forecast, on the supply side, through a gradual implementation of autonomous straddle technology across Australia's ports, it is possible to reach nearly threefold of today's cargo capacity in the year 2029-30.

Nationally, the average revenue increase by gradual implementation of autonomous straddle carrier technology in ports over a 17 year period is estimated to range between around $\$ 1.9-\$ 2$ billion every year. In the year 2029-30, it is expected to reach around $\$ 11.3-$ $\$ 12.9$ billion, and achieve accumulated NPV revenue of $\$ 32.1$ - $\$ 34.1$ billion over 17 years of deployment on a national level. Capacity is expected to gradually climb to 22.8 million TEU on a national level in the year 2029-30, which is expected to satisfy the demand for TEU handling across Australia as BITRE forecasts in the year 2029-30.

NSW is one of the States that can benefit the most from the introduction of autonomous straddle carrier technology, with the predicted productivity increase onl y slightly lower than Victoria. The two states combined account for more than $65 \%$ of all Australia's increase in cargo handling. This growth may have a significant impact on all indirect economic growth factors, as cargo freight affects many industries indirectly in particular the transportation industry. 
This technological innovation is a transformative technology for the Australian market and has the potential to have a significant effect across industries. However, in this study only the direct impact potential was investigated, which was found to be significant by itself, and could address the growing demand for higher freight in the market. 


\section{REFERENCES}

Australian Bureau of Statistics, 2012, ABS Australia 2012 year book.

Asciano, ASX Announcement, 2013, Financial year 2013: Full Year Financial Results.

Bureau of Infrastructure, 2011, Transport and Regional Economics (BITRE) Waterline 49, Department of Infrastructure and Transport, Canberra, Australia.

Bureau of Infrastructure, Transport and Regional Economics (BITRE), 2010,' Australian Maritime Activity to 2029-30', Canberra, Australia.

Deloitte Access Economics, 2012, Digital Disruption Short Fuse Big Bang?

Durrant-Whyte H. et.al, 2007, An Autonomous straddle Carrier for Movement of Shipping Containers - From Research to Operational Autonomous Systems, IEEE Robotics \& Automation Magazine.

Kalmar, Automatic Stacking Crane System, last time entered webpage 9February, 2015

http://webcache.googleusercontent.com/search?q=cache:ZvZT9aa3mAQJ:www.pods hop.se Lcontent/12/opensearchresult.aspx\%3Ffile\%3DSB-ASC-EN-

WW_L.pdf $+\& c d=1 \& h \mid=e n \& c t=c \operatorname{lnk} \& g l=a u$

Kalmar Press Release 2015, Kalmar to provide integrated automation system for Melbourne's new automated container terminal, last time entered webpage 9 February, 2015

http://www.cargotec.com/en-global/newsroom/Releases/press-releases/Pages/kalmar-toprovide-integrated-automation-system-for-1888237-Tue-20-Jan-2015-15-00.aspx

McKinsey Global Institute, 2013, Disruptive Technologies: Advances that will Transform Life, Business, and the Global Economy.

Patrick, 2012, Asciano Signs Contract for Automated Straddles for Port Botany, Media Release, 03 Sept 2012, last time entered webpage 9 February, 2015

http://asciano.com.au/news/articles/news/a/asciano-signs-contract-for-automatedstraddles-for-port-botany

Ports Australia, 2011-2012 Trade Statistics.

Port Jackson Partners, 2011, ANZ Insight, Earth, Fire, Wind and Water: Economic Opportunities and the Australian Commodities Cycle, Report commissioned by ANZ, Issue 1.

RF-Innovations: Leaders in Wireless data, last time entered webpage 9 February, 2015 http://www.rfinnovations.com.au/Uploads/Images/RF\%20Innovations\%20\%20Auto_Strad\% 20Application.pdf

United Nations Transport, Communications, Tourism and Infrastructure Development Division of ESCAP, Economic and Social Commission for Asia and the Pacific, 2006, Regional Shipping and Port Development Strategies: Under a Changing Maritime Environment. 


\section{APPENDIX}

According to Patrick, automating cargo straddle carrier technology in the port of Brisbane allowed them to increase their productivity by $39 \%$ (Patrick, 2012). Based on the assumption that port management companies would decide to keep spending the same amount on straddle handling cost with an increased capacity (rather than decrease straddle handling cost while maintaining the same increased capacity), the example below describes how percentage increase in TEU handling capacity and decrease in production costs is converted.

assuming $Q_{\text {old }} * P_{\text {old }}=\$ 100$

According to our data, by applying autonomous straddle technology, the port's production can increase by $39 \%$, (cost saving $28 \%$ ), this means:

$P_{\text {new }}=0.72 P_{\text {old }}$

If we keep handling the same quantity of TEU, costs will decrease

Cost $=\bar{Q}_{\text {old }} * 0.72 P_{\text {old }}$

Which means, now it is cheaper to produce the same quantity; however, we would like to keep spending the same $\$ 100$ and produce more quantity.

For simplification let's assume $P_{\text {old }}=\$ 1 \quad P_{\text {new }}=0.72 P_{\text {old }}$ therefore $P_{\text {new }}=\$ 0.72$

$Q_{\text {old }}=100$

cost $=Q_{\text {old }} * \$ 1=\$ 100$

$Q_{\text {new }} * \$ 0.72=\$ 100$

$Q_{\text {new }}=\frac{100}{0.72}=\$ 139$

$\$ 139$ is $39 \%$ more than $Q_{\text {old }}$ which was $\$ 100$.

If we take another example with different price, we will reach the same conclusion of a production increase of $+39 \%$ meaning a reduction in cost of $28 \%$.

The conclusion: an increase in production capacity of $39 \%$ (due to the improvement in the production process) would yield a reduction in costs of $28 \%$. i.e., $\%$ Cost reduction $=\left(\frac{\% \text { productivity improvement }}{1+\text { productivity improvement }}\right)$ 